\title{
"Seguir la caravana... pero no la movilización": diversidad de las memorias en las calles de un barrio de Córdoba, Argentina
}

\author{
Graciela María Tedesco
}

Este artículo se propone indagar los modos en que habitantes de un barrio de la ciudad de Córdoba,Argentina, ubicado junto a una fábrica automotriz, construyen memorias sobre las décadas de 1960 y 1970. Se analizan los recuerdos sobre las caravanas cotidianas de los trabajadores a la salida de la planta y sobre las movilizaciones sindicales que transitaban por las calles del barrio Santa Isabel. Las memorias sobre estos eventos nos ayudan a colocar la mirada en los lazos entre la vida cotidiana y los conflictos, $y$ a indagar en las ambigüedades y el dinamismo que tejen el pasado y el presente en este lugar.

PALABRAS CLAVE: memorias, espacio barrial, conflictos, vida cotidiana, vecinos, obreros, pasado reciente

\section{"Follow the Caravan... but not the Mobilization": Diversity of Memories in the Streets of a Neighborhood in Córdoba, Argentina}

This article purpose is to investigate how the inhabitants of a neighborhood of Córdoba,Argentina, located next to a car factory, build memories on the decades of 1960 and 1970. We analyze memories about the caravans of workers formed during the exit of the factory and about the union mobilizations in the streets of the Santa Isabel neighborhood. The memories on these events help us to place the look upon the links between the daily life and the conflicts, and to investigate the ambiguities and the dynamism that weaves the past and the present in this place.

KEYWORDS: memories, neighborhood space, conflicts, daily life, neighbors, workers, recent past 


\section{INTRODUCCIÓN}

$\mathrm{A}$ partir de una investigación etnográfica realizada entre 2008 y 2010 en el barrio Santa Isabel de la ciudad de Córdoba, Argentina, este artículo analiza el modo en que sus habitantes construyen memorias sobre dos eventos: las caravanas de trabajadores y las movilizaciones sindicales que transitaban por las calles de su barrio en las décadas de 1960 y 1970. Santa Isabel se ubica en la zona sur de la ciudad de Córdoba, donde a mediados de la década de 1950 se instaló una de las primeras plantas automotrices del país: Industrias Kaiser Argentina (IKA). La llegada de esta fábrica se vio favorecida por políticas de industrialización que dieron facilidades impositivas y crediticias para el asentamiento de empresas extranjeras en nuestra ciudad $^{1}$ y por la presencia en Córdoba de Industrias Aeronáuticas y Mecánicas del Estado (IAME), que proveyó mano de obra capacitada y asistencia técnica. Debido al impulso industrial, entre 1947 y 1960 la ciudad de Córdoba casi duplicó su población: de 380000 habitantes pasó a tener más de 590000 (Malecki, 2010). Hacia fines de la década de 1960, IKA empleaba a alrededor de 10000 personas, mientras que otro importante número trabajaba en comercios, pensiones, comedores y empresas de transporte vinculadas a ésta. Como señala Cristina Rocca: en pocos años "miles de personas se vieron involucradas con la empresa. Es por eso que 'la Kaiser', como decían los cordobeses, se ligó a la expansión industrial y a su imaginario de modernización y progreso" (Rocca, 2005: 54). Los 12 años que siguieron a

\footnotetext{
${ }^{1}$ Como Fiat - con sus plantas Concord y Materferd, y luego Grandes Motores Diesel-, IKA, Perkins, Conarg, etc. IKA se proveía de piezas e insumos fabricados en pequeños talleres distribuidos por la ciudad, en plantas como Transax - ejes-e ILASA - cables, componentes eléctricos y carburadores-, y en fábricas extranjeras, como Thompson Ramco y Associated Spring que se instalaron en Córdoba. Asimismo, en 1965 compró la Metalúrgica de Tandil en Buenos Aires y en 1966 la planta de Perdriel en Córdoba para construir máquinas y herramientas de alta precisión.
}

su instalación en 1955, IKA fue conducida por la firma estadounidense Kaiser. En 1967, parte de sus acciones fueron compradas por la Renault (Régie Nationale de Usines) de Francia, y cambió su nombre por IKA-Renault. Finalmente, en 1975 Kaiser vendió a Renault las acciones restantes y se retiró de Argentina.

En el plano político, a fines de 1955 un golpe militar interrumpió la presidencia de Juan Domingo Perón, ${ }^{2}$ lo envió al exilio y proscribió durante casi dos décadas al Partido Justicialista que lideraba. Durante este lapso se sucedieron varios gobiernos militares y dos periodos breves de presidencias radicales. ${ }^{3}$ Los sindicatos y los sectores estudiantiles surgieron en este contexto como actores colectivos de gran relevancia, de cuya actuación cabe destacar dos protestas colectivas que marcaron la historia local y nacional: el "cordobazo" en 1969 y el "viborazo" en 1971. ${ }^{4}$ A decir de Brennan y Gordillo: "la clase obrera cordobesa se convirtió en un actor político destacado entre 1966 y 1976, y estuvo en condiciones no

\footnotetext{
2 Juan Domingo Perón fue fundador del Partido Justicialista y presidente de Argentina en tres ocasiones -1946-1952, 19521955, 1973-1974, año de su muerte-. Durante su segundo mandato, el 16 de septiembre de 1955, estalló en Córdoba una sublevación militar encabezada por el general Lonardi, apoyada por algunos efectivos del ejército y de la aeronáutica, y por grupos civiles. Debió exiliarse a España, donde permaneció hasta 1973.

3 Presidencias de Arturo Frondizi -1958-1962- y de Arturo Illia -1963-1966-.

4 "El cordobazo" fue una protesta masiva ocurrida el 29 de mayo de 1969 y organizada por distintos sindicatos de Córdoba en resistencia a las medidas autoritarias de Juan Onganía — presidente de facto de 1966 a 1970—, quien cerró el Congreso, proscribió los partidos políticos e incrementó el control de la vida intelectual y cultural del país. En el plano económico, redujo el gasto público y generó las condiciones para una flexibilización laboral y el debilitamiento sindical. No obstante, el "cordobazo" implicó un serio revés a estas medidas y llevó a Onganía a renunciar. Se llamó el "viborazo" a una huelga general que tuvo lugar el 15 de marzo de 1971, luego de que el interventor provincial Camilo Uriburu declarara que "confundida entre la múltiple masa de valores morales que es Córdoba por definición, se anida una venenosa serpiente cuya cabeza pido a Dios me depare el honor histórico de cortar de un solo tajo", en clara alusión a los sindicatos cordobeses. En esta huelga se tomaron fábricas, empresas y reparticiones públicas, lo que causó las renuncias del interventor y del presidente de facto.
} 


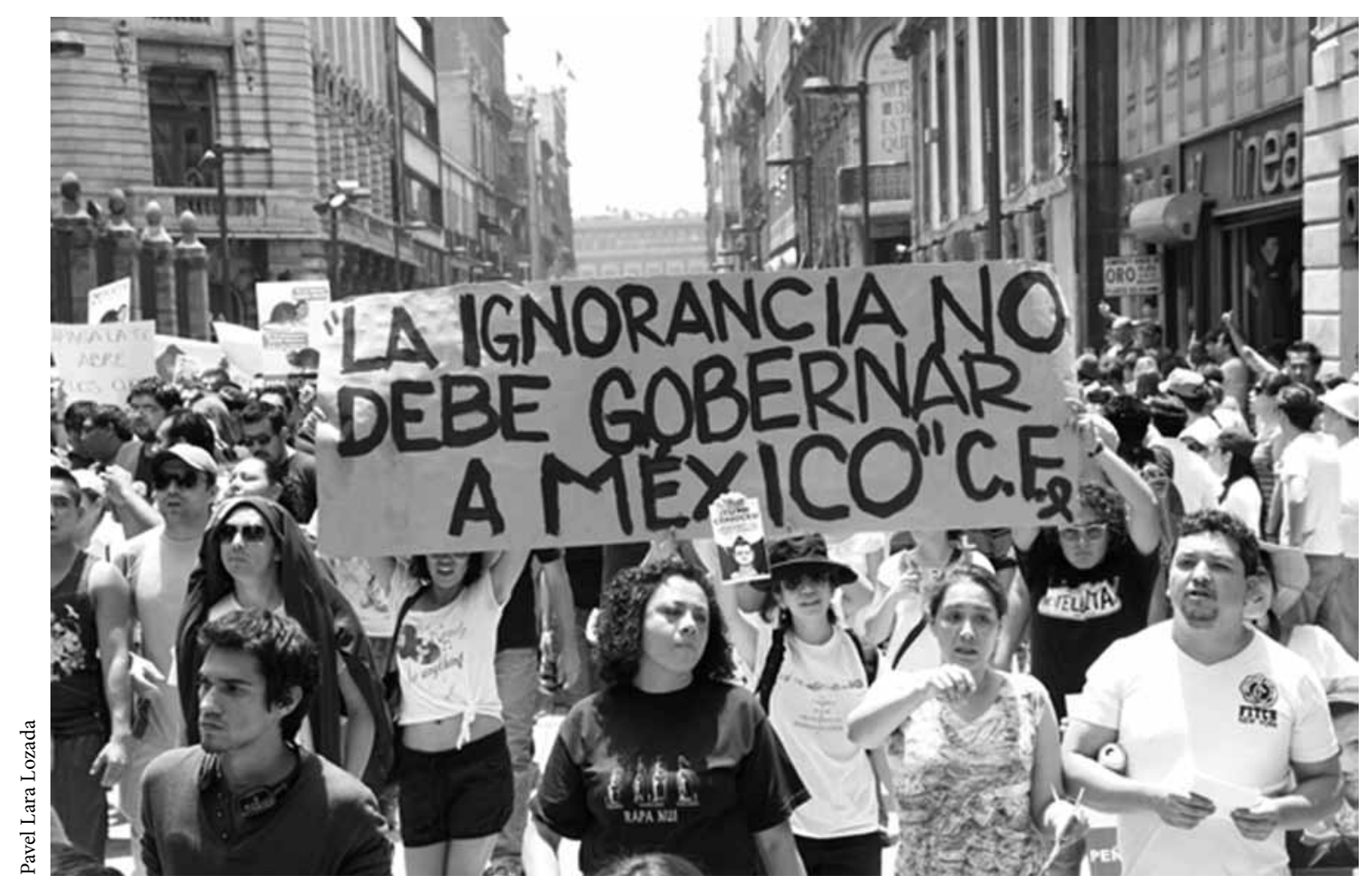

Manifestantes protestan en la ciudad de México contra Enrique Peña Nieto, candidato del PRI a la presidencia de México.

sólo de afectar la política local sino también de ejercer una influencia considerable en el plano nacional" (Brennan y Gordillo, 2008: 30). Por ese entonces, algunas agrupaciones de izquierda ${ }^{5}$ llevaron su mensaje revolucionario a sindicatos y organizaciones barriales, y se convirtieron en voces importantes que pedían el regreso de Perón a la presidencia. Sin embargo, esto no lograría calmar la creciente violencia política entre sectores de izquierda y de ultraderecha, lo que fue aprovechado por grupos militares y

\footnotetext{
${ }^{5}$ Entre ellas, las Fuerzas Armadas de Liberación (FAL), el Partido Comunista Revolucionario (PCR), la Vanguardia Comunista (vc), el Partido Revolucionario de los Trabajadores (PRT), el Ejército Revolucionario del Pueblo (ERP) y el grupo "montoneros". Es indudable que la Revolución Cubana - 1959- constituyó un impulso de envergadura para estos movimientos revolucionarios en América Latina. Si bien heterogéneos, tenían en común su postura "antiimperialista" y planteaban un cambio radical del sistema socioeconómico.
}

de elite para instaurar en 1976 una dictadura militar que se mantendría hasta 1983.

Las décadas de los años sesenta y setenta fueron centrales para los movimientos obreros en América Latina. Ocuparon un lugar preponderante los movimientos de Argentina, Brasil y México. Brennan (1996) sugiere que los gobiernos de Getulio Vargas en Brasil y Lázaro Cárdenas en México buscaron integrar a los sindicatos, que adoptaron una postura más pragmática pero supusieron también corrientes disidentes opuestas a las burocracias dominantes y a las políticas inequitativas gubernamentales. Éste fue el caso de los sindicatos ferroviario, eléctrico y mecánico en México y el del sindicato de trabajadores metalúrgicos en Brasil. Por su parte, la cooptación gubernamental en Argentina nunca se realizó del todo debido a los niveles significativamente más altos de sindicalización, a su singular estructura de clases y a los gobiernos militares resistidos 
en el poder. No obstante, precisa Brennan: "ninguno de estos movimientos parece haber representado una amenaza tan grande al Estado o una fractura tan completa de la forma de dirigir los asuntos gremiales como las del movimiento obrero disidente de Córdoba" (Brennan, 1996: 453). Éste es definido con frecuencia en la literatura por su carácter "rebelde" y por su vinculación con el clima también díscolo de una ciudad donde confluyeron el Movimiento de Sacerdotes del Tercer Mundo, la actuación de diversas agrupaciones de izquierda, así como la de un núcleo sólido de activistas sindicales marxistas y peronistas de izquierda y una alta participación política universitaria (Gordillo, 1999; Brennan y Gordillo, 2008). Asimismo, suele destacarse el apoyo de la población a dicho movimiento y también su componente popular. ${ }^{6}$ Cuando llegué con estas lecturas al campo, comencé a sentir cierta desorientación al advertir que mis entrevistados tomaban una marcada distancia de esas cuestiones y construían silencios y rechazos sobre ese pasado sindical rebel-
Más allá de profundizar en una mirada etnográfica respecto de las particularidades del caso cordobés, este trabajo pretende complejizar aquellas lecturas únicamente políticas con las que muchas veces se repara en los movimientos obreros latinoamericanos, a fin de comenzar a construir reflexiones conjuntas en torno a los procesos sociales, las sensibilidades y los prestigios que se ponen en juego, y en relación con los modos de construir encuentros y desencuentros entre las memorias de los protagonistas de dichos movimientos y los residentes de la ciudad. En la primera parte del artículo se indaga en aquellas evocaciones relativas a las caravanas que efectuaban los trabajadores al finalizar cada turno laboral en tanto eventos cotidianos y significativos para los antiguos vecinos de Santa Isabel. En la segunda parte se examinan las memorias en torno a las movilizaciones o protestas sindicales realizadas en aquella época como acontecimientos que adoptan un tono excepcional y conflictivo entre los entrevistados. De este modo, se recorren memorias sobre los diferentes usos de las calles en este barrio, vinculadas a la imagen que las personas que conocí construyen sobre su lugar de residencia y sobre sí mismas.

\section{NOTAS TEÓRICO-METODOLÓGICAS} acerca de la fábrica y el movimiento obrero en las décadas de 1960 y 1970 . No me concentro en los conflictos obreros en sí, sino en la manera en que las personas que residen al lado de una fábrica automotriz recuerdan desde el presente las caravanas de trabajadores y las movilizaciones sindicales que transitaban por las calles de su barrio décadas atrás.

\footnotetext{
${ }^{6}$ Por ejemplo, en Topografía de la rebeldía (Comisión y Archivo Provincial de la Memoria, 2009: 2) se enuncia: "Hace cuarenta años, Córdoba vivió una rebelión popular que generó una bisagra en la historia de la provincia y del país. Los eventos de esos largos días de participación ciudadana, fueron bautizados como "el cordobazo". [...] Desde los sindicatos, organizando columnas de acción; desde las universidades y colegios apoyando a los obreros; desde cada cordobés que con amigos o solo decidió participar de la gesta".
}

La investigación etnográfica de la que surge este trabajo se desarrolló en el marco de mi tesis de doctorado en ciencias sociales (Tedesco, 2010), en un barrio de la ciudad de Córdoba donde se emplazó una fábrica automotriz décadas atrás. El uso de diversas herramientas metodológicas me posibilitó acceder desde distintos lugares a los discursos y prácticas de sus residentes, a fin de comprender el modo en que construyen sus memorias. Así, la observación participante fue una herramienta fundamental en mis recorridos por el barrio y en las actividades de las instituciones y las organizaciones barriales -Centro de Jubilados, Centro Vecinal, biblioteca barrial, clubes, escuelas- en las que 
participé. Por otra parte, la clasificación y revisión del archivo de notas producidas por el Centro Vecinal de Santa Isabel entre 1953 y 2002, que se encuentra en la Biblioteca Popular, permitió ampliar mi comprensión sobre la trayectoria barrial y sus puntos de encuentro con la fábrica. Las entrevistas y charlas informales durante mis visitas frecuentes a sus casas fueron la principal herramienta para conocer las experiencias y los imaginarios de los vecinos. ${ }^{7}$ El hecho de preguntar sobre décadas pasadas hizo que mis entrevistados supusieran que estaba escribiendo una "historia del barrio" y que tenía que hablar con los vecinos más antiguos. Debido a esto, me presentaron sucesivamente a personas que tenían una residencia prolongada en el barrio y habían sido testigos de diferentes épocas. Otro grupo de entrevistados, aunque numéricamente menor, fue el formado por los hijos de estos vecinos antiguos, quienes habían crecido en el barrio y que en muchas ocasiones conocí en las casas de sus padres. Asimismo, realicé entrevistas a un grupo heterogéneo de personas de Santa Isabel y barrios aledaños, con diversas ocupaciones y tiempos de residencia en la zona. Estos entrevistados aportaron un rico material que se despegaba de las miradas "idealizadas" sobre el barrio y presentaban otras formas de recordar y residir. La revisión de documentos, planos y fotografías de la oficina del Catastro Municipal y la lectura de ordenanzas y de diarios publicados entre 1950 y 1980 enriquecieron el material de análisis. Finalmente, la reflexión constante sobre mi lugar como investigadora, visita, amiga, etc., sobre el lugar en el que mis entrevistados se ubicaban para recordar y sobre los registros que fui construyendo, fue otra pieza fundamental del trabajo de campo.

\footnotetext{
${ }^{7}$ Se realizaron 27 entrevistas grabadas individuales y 10 a matrimonios, la mayoría implicó dos o tres encuentros, a fin de profundizar en los temas que iban surgiendo. Por otra parte, mantuve charlas informales con alrededor de 15 personas más, pero tratando temas puntuales que me ayudaron a contextualizar o ampliar lo revelado durante las entrevistas.
}

\section{“SEGUIR LA CARAVANA...": MEMORIAS SOBRE LOS TRABAJADORES EN LAS CALLES}

El recuerdo sobre las salidas multitudinarias de la fábrica en cada cambio de turno de trabajo en las décadas de 1960 y 1970 surgió con frecuencia en las conversaciones con los vecinos. En esa época la planta tenía tres turnos de trabajo: mañana, tarde y noche. El que concentraba la mayor cantidad de trabajadores era el de la mañana, de 7:30 a 16:18 $\mathrm{h},{ }^{8}$ y es también el más recordado por los vecinos. Las salidas de la fábrica o las caravanas evocaban a los miles de trabajadores que salían juntos por la calle principal de Santa Isabel al anunciarse con una sirena el fin de su turno laboral. Los obreros atravesaban el barrio caminando, manejando motos, bicicletas, autos, o en colectivos hacia sus hogares. La multitud colmaba el barrio en ese momento y obligaba a los vecinos a esperar a la vera del camino para luego retomar sus actividades. Estas narraciones, escuchadas decenas de veces durante el trabajo de campo, eran acompañadas por una emoción que se exteriorizaba en el rostro y los gestos de quien hablaba. Aunque contada de diferentes maneras, los puntos centrales de esa memoria quedan de manifiesto en la siguiente reconstrucción realizada a partir de diferentes relatos recogidos durante la investigación:

\begin{abstract}
A las 4:18 $\mathrm{h}$ la sirena de la fábrica comenzaba a tocar y los empleados del turno de la mañana se preparaban para abandonar la planta. Aquellos que vivían cerca, salían sin demora caminando o en bicicleta, pero quienes tenían un viaje más prolongado hacia sus casas se dirigían a los vestuarios a cambiar su ropa de trabajo. En la explanada, decenas de colectivos particulares aguardaban a los obreros. Otro conjunto de trabajadores formaban fila en la parada del ómnibus urbano, que iniciaba su recorrido al llenarse. Algunos empleados compraban café o sándwiches a los niños
\end{abstract}

${ }^{8}$ La jornada duraba ocho horas, a las que se sumaban 48 minutos para compensar el sábado no laborable o sábado inglés. 
que esperaban a la salida de la fábrica con sus canastas. Por la avenida que atraviesa el barrio comenzaban a pasar las primeras motos y en pocos minutos cientos de ellas dejaban escuchar el zumbido de sus motores por todo Santa Isabel. También aparecían autos llevando empleados y por último se sumaban a la caravana los ómnibus particulares que trasladaban a los obreros hasta localidades del interior. La interminable fila de motos y autos era aguardada por la policía en la intersección de la ruta a fin de guiarla y controlar los límites de su velocidad.

Desde la vereda algunos chicos jugaban a contar cuántos ómnibus pasaban por la calle. Algunas personas miraban desde las ventanas de las casas y aquellas que no habían logrado cambiar de vereda esperaban pacientemente que el paso de los trabajadores menguara. Asimismo, los vecinos que no habían podido tomar un colectivo urbano antes del horario de salida de la fábrica debían aguardar que éstos dejaran de pasar repletos y que se detuvieran en las paradas del barrio. Luego de un rato, la quietud comenzaba a volver a las calles. Sólo se veían algunos empleados rezagados que preferían esperar a que salieran los demás para regresar sin apuros, mientras que otros se detenían en los bares de la avenida para "picar algo", tomar alguna
Como lo constata esta reconstrucción de una caravana, los trabajadores son rememorados en su movimiento de salida de la fábrica. Ellos atraviesan la calle principal del barrio en conjunto, ya sea subidos a diferentes vehículos - bicicletas, motos, autos, ómnibus - o caminando. La caravana es cotidiana y comienza en un momento exacto, que inicia con el sonido de la sirena. A su vez, la presencia de los vecinos en las veredas transforma la caravana en desfile, en tanto que observan y admiran a la multitud trabajadora pasar. El recuerdo de esas salidas de la fábrica indica que las actividades del barrio se frenaban con las caravanas y que los vecinos prestaban la calle a los trabajadores. Según los entrevistados, lo único que se podía hacer era esperar:

Entre los que salían y los que entraban, tenías casi dos horas que no podías cruzar la avenida de un lado al otro. Obviamente, ni salir a tomar el colectivo, ¿para qué? (Patricia, 46 años, docente, julio de 2009).

Sofía, quien vive sobre la avenida principal, decía en relación con la caravana que pasaba frente a su casa:

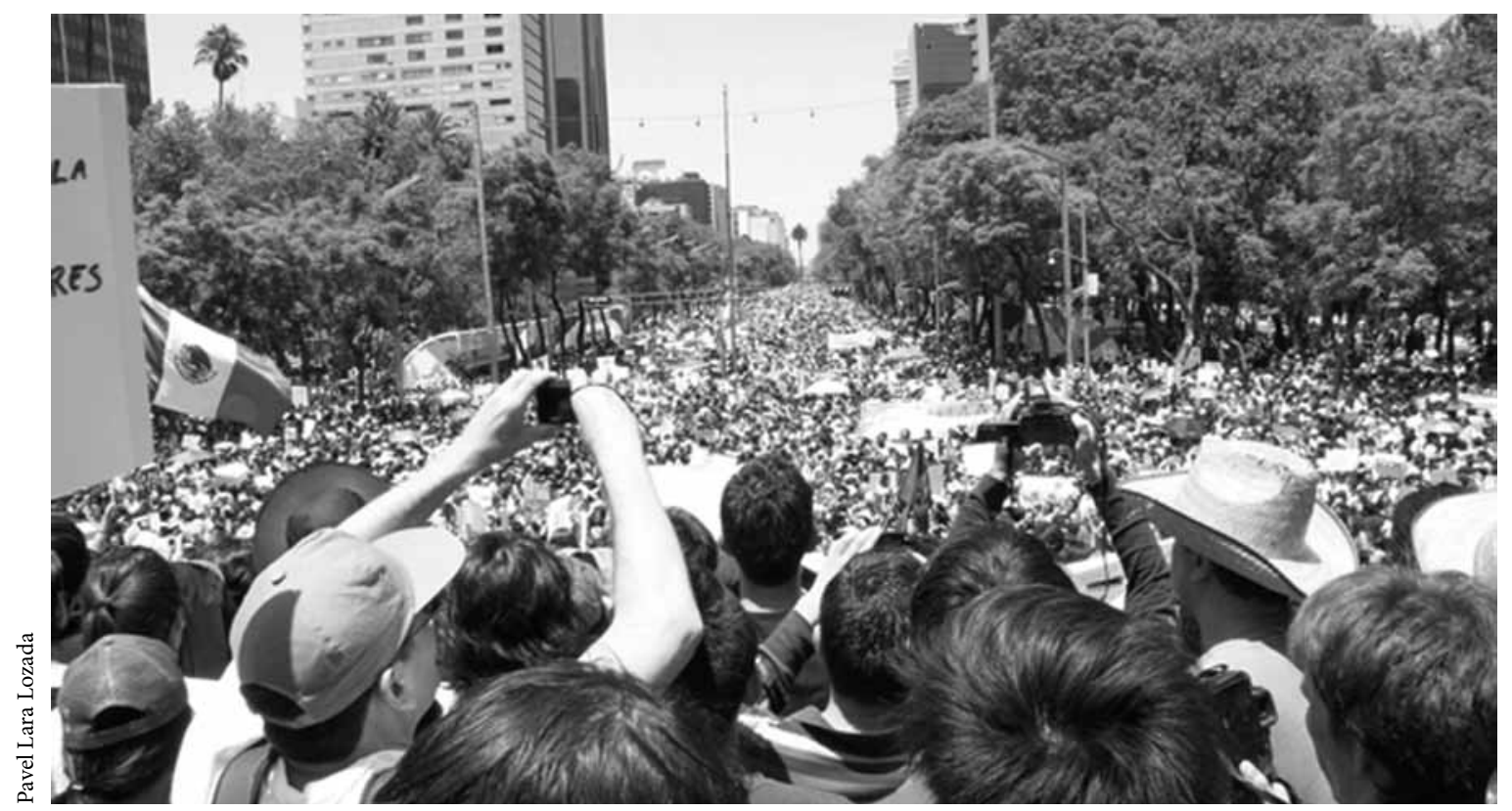

Megamarcha convocada por \#YoSoy132 y otras organizaciones sociales en contra del candidato del PRI Enrique Peña Nieto, en la ciudad de México, 2012. 
¡Uhhh! Una hora no podías cruzar. En esa época eran todo motos, motos, coches, colectivos. Me acuerdo que una vez vino mi papá y se sentaba, 60 colectivos para llevar a gente de Alta Gracia, Río Ceballos y no había otra calle, era ésta nomás. No se podía cruzar. Y a veces invitábamos a gente de Santa $\mathrm{Fe}$, así y se quedaban admirados (Sofía, 78 años, ama de casa y comerciante jubilada, julio de 2009).

Las actividades barriales se realizaban teniendo en cuenta los turnos de entrada y salida laboral de la fábrica. El tránsito constituía un espectáculo que podía presenciarse todos los días:

Esa época extraordinaria. Donde uno, por la avenida Renault, cuando salían había que esperar media hora para pasar. Era algo tan... Yo los sabía llevar a los chicos para que vieran. A las 4:18. Era una belleza, me llenaba de orgullo. Parecía un país floreciente..., una belleza (Ernesto, 74 años, empleado público jubilado, noviembre de 2008).

En el relato de Ernesto aparece la sensación de orgullo producida por el paso de los trabajadores, vinculada a una época de prosperidad en el país y a la niñez de sus hijos. ${ }^{9}$ Los operarios que transitan por las calles del barrio corporizan de esta manera el trabajo y el nexo entre su lugar de residencia y la comunidad nacional más amplia. Si bien la referencia más común es la de "ir a ver" la caravana de los trabajadores, hay otras narraciones, como la de Irina, que hablan de una participación dentro de la caravana. A veces, para divertirse, Irina "se metía" con su moto en la caravana y lograba confundirse entre los miles de obreros.

Graciela (G): ¿Cuál era la relación entre la fábrica y el barrio?

\footnotetext{
${ }^{9}$ En varias de las notas que se encuentran en el Archivo del Centro Vecinal Santa Isabel pueden leerse pedidos realizados por el Centro Vecinal a las autoridades municipales para la mejora del servicio de transporte en los horarios pico y para controlar la velocidad de los vehículos de la caravana para evitar accidentes. No obstante, en los relatos actuales de los vecinos la caravana no aparece como algo conflictivo o peligroso.
}

Irina (I): Vos sabés que salías de la fábrica a las 4:18. Yo tenía una moto de tres ruedas y tenía una pollera ${ }^{10}$ ancha y a las cuatro y algo salía a la ruta y me iba con la caravana. [...] Y te decían: "siga la caravana", y yo hay veces que me salía. Y me encantaba. Con la caravana pasábamos el canal y seguíamos.

G: ¿Y eso en qué época?

I: Ponele que ha sido hasta el 75 (Irina, 75 años, empleada de comercio jubilada, diciembre de 2008).

Para Irina meterse en la caravana supone transgredir el hecho de que sólo pasaran obreros y muestra la interacción con ellos. En este sentido, ella no mira desde afuera a los trabajadores, sino que ingresa a la caravana y se mezcla con ellos. Asimismo, señala que las caravanas ocurren hasta 1975, época que coincide con la fecha en que los directivos estadounidenses dejan la empresa y con la profundización de la violencia política. Los protagonistas de las caravanas son los trabajadores de Kaiser y cuando se los recuerda en su paso por las calles parecen no mostrar jerarquías ni divisiones. Al hablar de los trabajadores de Kaiser los vecinos hacían referencia a personas que tenían una elevada calificación y buen acceso al consumo y a la educación. No obstante, también relatan que luego vendrían nuevos tiempos y esto cambiaría.

\section{LO QUE SE FUE PERDIENDO...}

Las memorias, como enseñó Halbwachs (2004), se originan socialmente y su existencia es un dato del presente que puede ser comprendido en relación con marcos sociales actuales. Las memorias no suponen sólo representaciones del pasado, sino también "modos de sentir, modos de querer, pequeños gestos, prácticas, acciones políticas innovadoras" (Gondar y Dodebei, 2005: 24). Involucran entonces fuerzas que nos afectan y por las cuales afectamos, dimensiones éticas y políticas con las cuales

\footnotetext{
${ }^{10}$ Falda de mujer.
} 
actuamos en función de un futuro anhelado. Así, las memorias se encuentran en permanente disputa y construcción, constituyen "ese entretejido de tradiciones y memorias individuales, en diálogo con otros, en estado de flujo constante" (Jelin, 2002: 22). De este modo, el recuerdo de un tiempo en el que los obreros tenían una buena posición económica, transitaban orgullosos por las calles y poseían una alta calificación fue acompañado en las entrevistas por la referencia a que esto ya no formaba parte del presente. Algunos vecinos señalaron que en la actualidad la mayoría de las familias de la zona "son de clase media baja, pero antes era clase media" (Violeta, agosto de 2009). Indicaron, además, que la mayor parte del trabajo en la planta fue trasladado a empresas contratistas que se especializan en distintas tareas y que el personal empleado disminuyó por la alta tecnificación y la compra de piezas en fábricas de autopartes para el armado de autos:

La computación se usa, se ha tecnificado mucho. Pero aparte de eso, los que trabajan armando el vehículo, viene el tren delantero y lo ponen completo. Antes había que armar pieza por pieza el costado, después ponerlo, la fábrica de tanques de combustible estaba adentro, todo eso fue el cambio que hubo. Aparte, los modelos de auto se fueron tecnificando de tal forma que nada que ver (Francisco, 54 años, dueño de una empresa de vehículos especiales, septiembre de 2009).

La tecnificación y flexibilización laboral que rodea a los nuevos operarios implica diferencias respecto de los antiguos trabajadores vinculados a sentimientos de prestigio social y orgullo. En relación con esto, Beaud y Pialoux (2006) intentan comprender el proceso de desestructuración de la antigua "clase o elite operaria”, a partir del cual el nuevo personal calificado adopta un perfil técnico y sus aspiraciones se vuelven hacia las clases medias, despegándose de todo lo que pueda evocar su condición operaria. Lo que fue desapareciendo para estos autores fue la figura del trabajador orgulloso de su trabajo y de su contribución a la producción, o la de obrero apoyado por su "clase", portadora de historia y objeto de atención política, como ocurría en 1960 y 1970.

Entre las personas que entrevisté en Santa Isabel la pérdida del reconocimiento y el prestigio de los trabajadores de la fábrica se encontraba enlazada a la partida de los estadounidenses de Kaiser - que vendieron en 1975 todas sus acciones a Renault-y al ingreso de personas de agrupaciones de izquierda a la planta. $\mathrm{Al}$ indagar sobre esta cuestión, varios entrevistados manifestaron que los estadounidenses se habían ido porque "los sindicalistas hacían muchos paros" o porque "los montoneros no trabajaban como tenía que ser". En sintonía con esto, observé que cuando hablaban de las caravanas de trabajadores se referían en particular a las de la época de IKA e IKA-Renault durante 1960 y 1970, y a veces también a las que tuvieron lugar con Renault hasta promediar la década de los ochenta, en tanto que la mención a las movilizaciones y tomas de fábrica bravas apuntaba a las producidas en los primeros años de la década de 1970, recordadas por sus altos componentes de violencia. A partir de esta cuestión, se analizan a continuación los sentidos que adoptan para los vecinos los conflictos sindicales desarrollados sobre el final de la época de los estadounidenses en Kaiser y al aumentar la violencia sociopolítica en el país.

\section{"PERO NO LA MOVILIZACIÓN": MEMORIAS SOBRE LOS CONFLICTOS EN LAS CALLES}

7:35 y 4:16 salían... 4:18. Y cuando veíamos que salían entre medio, decíamos: “qué pasó, qué pasó?”. ¿Qué pasaba? Paro. Claro, porque tenían todo el uniforme color verde, entonces vos sabías que eran los operarios de la fábrica. Entonces te llamaba la atención e ibas como chico curioso a preguntarles qué es lo que pasaba. Y nos decían que había paro (Patricia, 46 años, docente, julio de 2009).

Como recuerda Patricia, los paros o movilizaciones ocurrían en horarios no acostumbrados e indicaban 


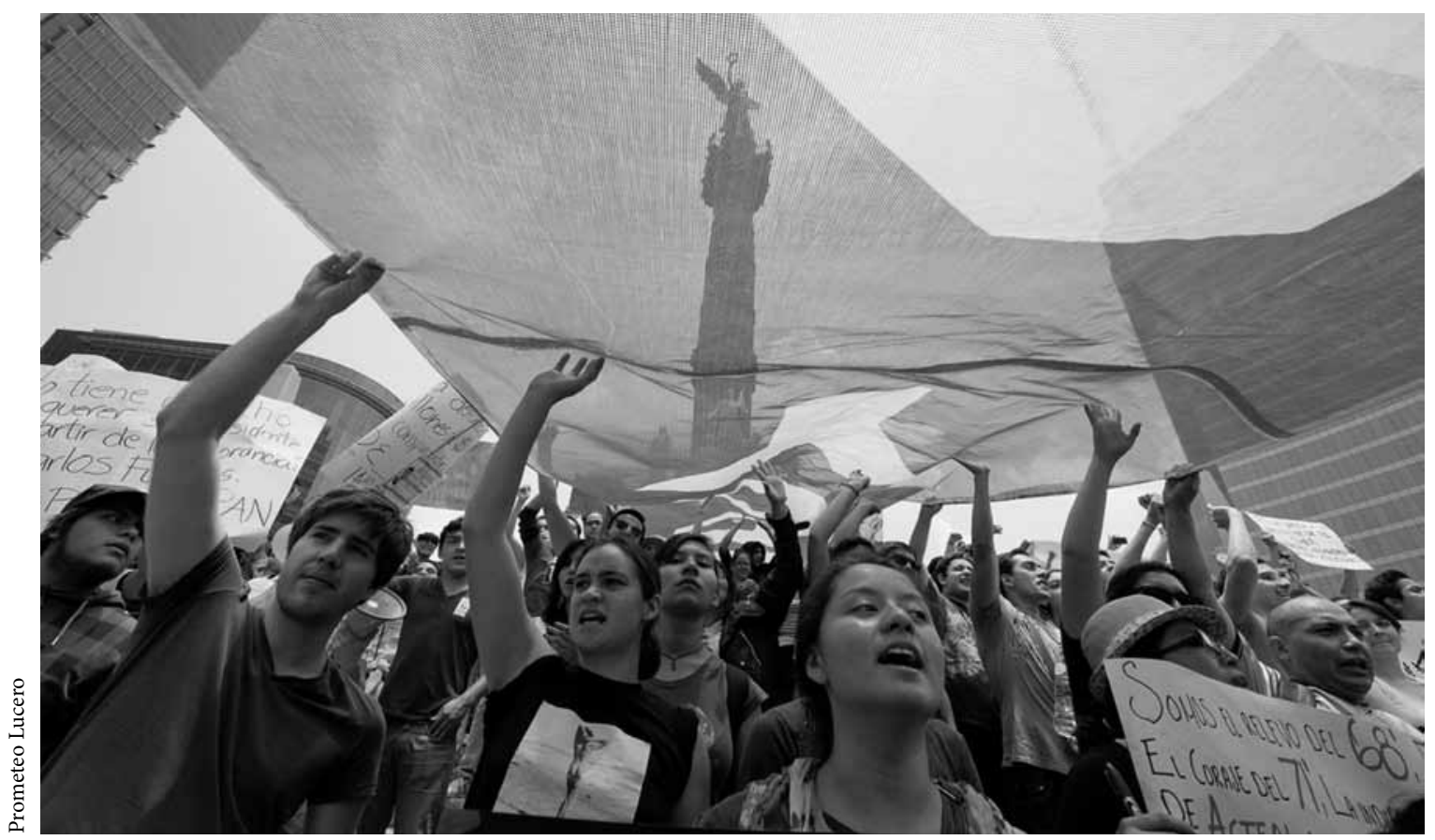

Marcha \#YoSoy132 hacia Televisa, en la ciudad de México, 24 de junio de 2012.

que algo fuera de lo común estaba sucediendo. Otros testimonios advierten que en las movilizaciones las calles parecían "invadidas" por los manifestantes y no ya cedidas por el barrio al paso de los trabajadores. Los recuerdos sobre las protestas sindicales surgieron sólo cuando pregunté directamente por ellas, dado que al parecer no formaban parte de recuerdos que quisieran ser contados a alguien "que se encontraba escribiendo una tesis sobre el barrio". Formaban parte de una época en la que el barrio pasó de estar ligado al progreso de la fábrica a ser asociado con los paros y protestas. De esta manera, a la convivencia y al orgullo de la caravana, se opuso el conflicto y la vergüenza de la movilización.

Un día pregunté a Camilo (88 años, capataz de IKA y Renault jubilado) si había ocurrido algo en el barrio o en la fábrica durante el "cordobazo". Mirándome y sin dudar, respondió que "no había pasado nada”. Intenté disimular mi sorpresa puesto que sabía que la columna más importante de obreros que participó había salido de la planta de Santa Isabel. Un hecho similar reportado por Federico Neiburg (1988) en su investigación sobre una fábrica cementera en Buenos Aires me resultó esclarecedor. Neiburg anota que al preguntar: “¿qué había pasado en 1955?” —año del derrocamiento de Perón por la llamada "Revolución Libertadora"-, la respuesta fue: "no, aquí no pasó nada”. La comprensión de esta cuestión residía en que, como pudo percibir, los beneficios dados por Perón hasta ese momento pasaron a ser entregados por el patrón de la fábrica, por lo que para sus entrevistados muy poco había cambiado. La respuesta de Camilo tal vez podía entenderse en esa dirección. Según diferentes testimonios recogidos en el barrio, a fines de 1960, cuando ocurrió el "cordobazo", la empresa no había modificado aún su política empresarial, sino que esto comenzó a suceder de manera palpable en los primeros años de 1970. Los entrevistados destacaron también que las tomas de fábrica realizadas en tiempos de IKA eran "más tranquilas": 
Con la Kaiser era muy fácil pedir aumento de sueldo porque siempre lo daban, pero cuando llegaron los franceses se le hizo más difícil a los sindicatos pedir aumentos (Sebastián, empleado de IKA y Renault jubilado, julio de 2009).

Si bien las tomas de fábrica, las huelgas y las asambleas no eran extrañas a la cotidianidad fabril, las que se produjeron a comienzos de los setenta fueron rememoradas como "más bravas", debido a los conflictos que se intensificaron con las políticas de modernización y racionalización traídas por Renault, que supusieron una estricta disciplina fabril, el aumento de los ritmos de producción y la reestructuración del complejo. En coincidencia con ese momento, en 1972 la Lista Marrón, encabezada por René Salamanca, ${ }^{11}$ del Partido Clasista Combativo, gana la Secretaría General del Sindicato de Mecánicos y Afines del Transporte Automotor (sMATA). Esto genera cambios en las estrategias de lucha del sindicato, con huelgas más violentas y prácticas de trabajo a desgano y a reglamento que buscaban la menor productividad, a fin de ser escuchados. De este modo los obreros manifestantes asumen un papel más visible y transgresor. La llegada de personas de izquierda a la fábrica fue recordada también por Felipe durante una entrevista en su casa junto a su esposa Vivi.

Felipe (F): Salamanca todos los días paro. Antes estaba el de Alta Gracia, Torres. ${ }^{12}$ Con ése se trabajaba tranquilo. Entró éste al sindicato y todos los días paro, lío, hasta que el avión lo ha tirado al dique.

Graciela (G): ¿Eso dicen?

\footnotetext{
11 René Salamanca ingresa a IKA-Renault como activista del Partido Comunista Revolucionario (PCR) en 1969, luego del "cordobazo". En 1970 participa en una elección de delegados y su victoria no es reconocida porque tenía menos de un año de afiliación. Al año siguiente gana nuevamente como subdelegado. En 1972 se presenta en las elecciones del smata con la Lista Marrón y gana. En 1974 es reelegido pero el smata Central no reconoce su triunfo y poco después se decreta la intervención del sindicato. El 24 de marzo de 1976 es secuestrado y desaparecido.

${ }^{12}$ Elpidio Torres, peronista, fue secretario general del sMATA entre 1958 y 1971.
}

F: Pero sí, Salamanca. Por pavadas hacían paro. ¡Perdimos plata! Claro, no trabajábamos y no nos pagaban (80 años, operario de IKA y transportista de Renault jubilado, noviembre de 2009).

Felipe fue operario de la fábrica hasta fines de 1960. Cuando se vendió la sección en la que trabajaba, compró un camión y se convirtió en transportista. En su relato plantea que mientras en la época de Elpidio Torres frente al sindicato se "trabajaba tranquilo", durante la gestión de René Salamanca "todos los días había paro" y no se podía trabajar. Para Felipe la frecuencia de los paros los tornaba cotidianos y debilitaba su ingreso económico, que dependía de la fábrica. La finalización de los paros y conflictos se produce, según él, cuando Salamanca desaparece: "hasta que el avión lo ha tirado al dique". La desaparición física de Salamanca combina la información que se dio a conocer en los medios de comunicación acerca de "los vuelos de la muerte" -en los que tiraban al Río de la Plata los cuerpos de personas secuestradas por la última dictadura militar, 1976-1983- y una versión más local que refiere que los cuerpos desaparecían en algunos diques de Córdoba. Este relato evidencia la construcción de una memoria local y nacional al mismo tiempo, que mezcla diferentes experiencias.

Eusebio (73 años, operario de Renault jubilado), quien vive desde fines de 1960 en la Segunda Sección de Santa Isabel, aseguró durante su entrevista que siempre había sido peronista y que René Salamanca "era zurdo". Sin dejar de reconocer que Salamanca "luchaba mucho para el obrero", Eusebio centró su recuerdo en su salida del sindicato y en su desaparición, por la que "nunca más supimos qué pasó". La oposición entre peronista y "zurdo" parece para Eusebio una verdad autoevidente que pone en tensión dos términos cargados de emotividad. La sensación dentro de la fábrica de que la desaparición de Salamanca y de otros obreros era algo que no podía explicarse, pero que encontraba su origen en ser "zurdo", suponía que en ese "no saber qué les había pasado" estuviera implícito que era mejor no 
buscar explicaciones. Emilio vive desde comienzos de 1970 en la Primera Sección y mientras conversábamos en su casa señaló:

Salamanca era un hombre apuesto y hablaba muy bien. Cuando se hacían asambleas se paraba sobre algo más alto para hablar y todos se quedaban escuchando. A mí me gustaba Salamanca y Tosco, pero no decía nada para que no me tildaran de "zurdo". Entonces, yo calladito, nunca me metí en ésas (Emilio, 76 años, operario de IKA y Renault jubilado, abril de 2008).

El recuerdo de Emilio sobre la admiración que sentía por Salamanca es acompañado por el cuidado de verse obligado a guardar silencio para evitar que "lo tildaran de zurdo". La expresión "zurdo" parece haber sido descalificadora entre sus compañeros de trabajo, si bien en 1972 y 1974 se eligió de forma consecutiva una conducción de izquierda para el sindicato. Se observa en este tenor una flexibilidad en aquellos empleados que, sin dejar de ser peronistas, apoyaron la gestión de Salamanca y posteriormente no se opusieron a la decisión del sMATA Central de Buenos Aires de reemplazar al clasismo por una comisión "normalizadora" peronista y en línea con éste, que llega hasta el presente. ${ }^{13}$

\section{De “negros" y “zurdos"}

Si bien algunos trabajos históricos realizados en Córdoba (Brennan, 1996; Gordillo, 1999; Brennan y Gordillo, 2008) resaltan la importancia del carácter "rebelde" de la lucha obrera en esa provincia, percibí que en Santa Isabel los vecinos tenían una perspectiva distinta sobre esta cuestión. Sus relatos dejan ver en primer lugar una clara distinción entre el

\footnotetext{
${ }^{13}$ El 8 de agosto de 1974, el smata Central resolvió expulsar del gremio a la totalidad de la Comisión Ejecutiva de la Seccional Córdoba, dirigida por Salamanca, declarar el estado de acefalía y designar una comisión normalizadora para que se hiciera cargo de la seccional.
}

transitar cotidiano de los trabajadores y el paso excepcional de la movilización, aun cuando la mayoría de las personas que integraban las dos salidas eran las mismas. Por ejemplo, Celeste y Vera, en una entrevista a solas en el Centro de Jubilados de Santa Isabel, narraron:

Celeste (c): Y cuando salían en manifestación, salían caminando la gran mayoría.

Graciela (G): Ah. ¿Ahí dejaban las motos?

C: Más que todo era caminando. Era otra cosa.

Vera (v): Pero eso fue al último...

C: Y la época antes del 70 fue ya. Porque después, cuando hubo el "cordobazo", toda esa cosa. Mataron a uno de Kaiser, Mena.

v: Fue un desastre, que mataron a no sé cuántos.

C: Mataron a un tal Mena e incendiaron en dos oportunidades una venta de automóviles, ahí sobre la ruta frente del canal, en poquito tiempo, en dos salidas de "los negros de Kaiser" como le decíamos, y no sé por qué.

v: Las tomas de fábrica se hacían en la fábrica.

G: ¿Pero no implicaban salir?

v: No, ahí se quedaban. Mi marido trabajaba ahí pero era empleado, a los empleados se los dejaba. Los operarios no. Son diferentes.

c: Tiros, bombas, viste. Siempre había lío. Especialmente esa vez, que fue la vez que yo más me acuerdo. Porque en las demás salían ellos y se iban y se iban. Nosotros íbamos a trabajar y no nos enterábamos de nada. Pero esa vuelta hubo tiros, hubo más bochinche, más corridas, más cosas, estaban los militares. Había carros de militares (Celeste, 70 años, modista jubilada; Vera, 68 años, ama de casa, mayo de 2009).

Celeste y Vera marcan continuidades entre el "cordobazo" y otras movilizaciones en las que se evidencian conflictos, muertes e incendios, y se colocan en un lugar alejado de las manifestaciones: "nosotros íbamos a trabajar y no nos enterábamos de nada". La expresión "los negros de la Kaiser" con la que identifican a sus protagonistas refuerza la distancia respecto de quienes pasaban por las calles. Esta cuestión tiene reminiscencias del "cabecita negra" del interior del país que se trasladaba a las grandes 


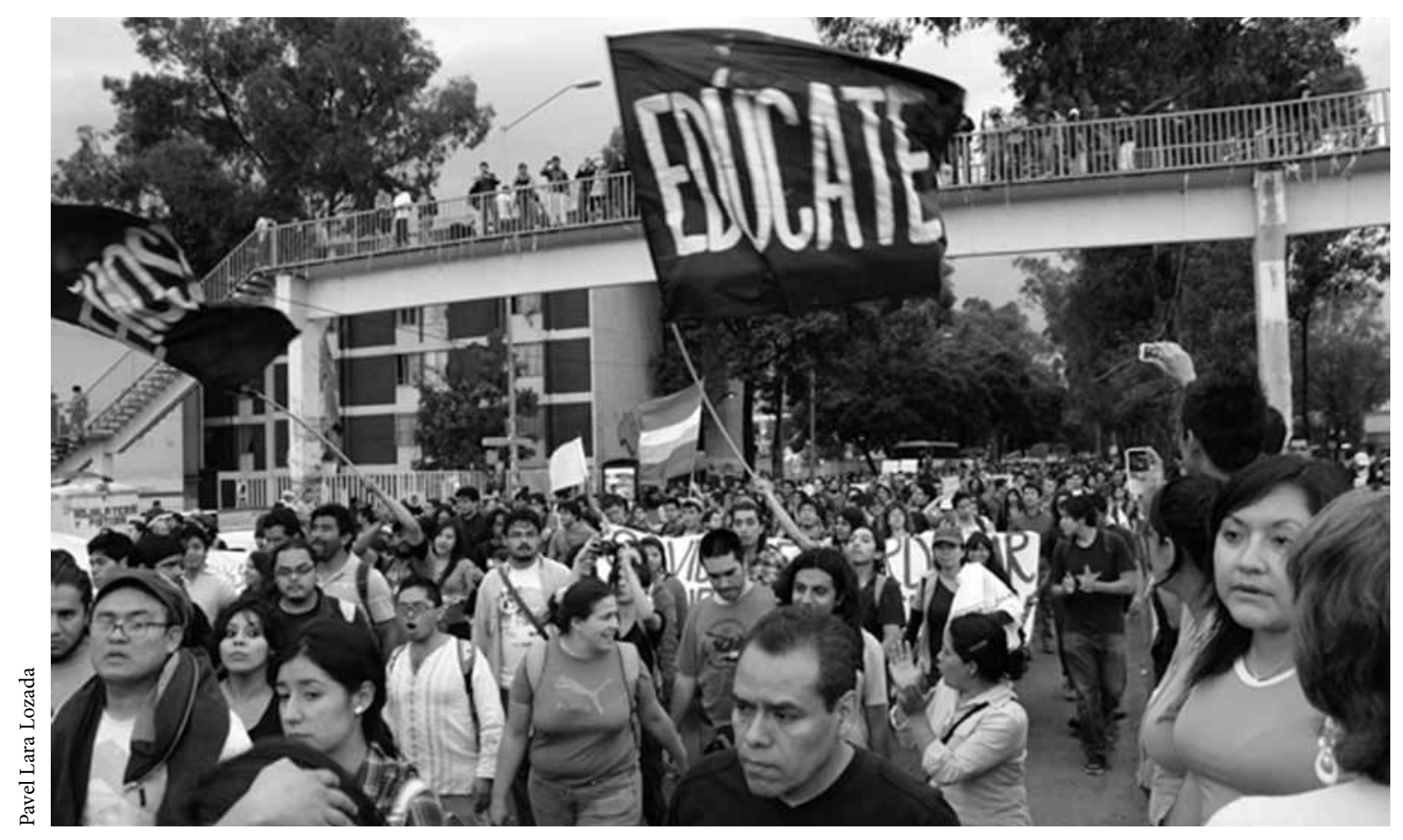

Estudiantes de la Universidad Nacional Autónoma de México e integrantes del \#YoSoy132 se dirigen a las instalaciones del Tribunal Electoral del Poder Judicial de la Federación, 2012.

ciudades en la década de 1940. Hugo Ratier (1972) sugiere que el prejuicio racial fue una de las maneras de enfrentar el choque cultural producido por este "migrante interno" llegado masivamente y que cobró fuerza a partir de las políticas sociales impulsadas por el peronismo. En este sentido, también en Santa Isabel la categoría "negros" es un recurso usado para debilitar al grupo obrero que en ese momento concentraba gran poder, pero que irrumpía en la cotidianidad del barrio en perjuicio de su reputación. A decir de Vera ese tipo de protestas más violentas ocurrieron "al último" y quienes participaban en ellas eran los operarios, mientras que el personal con cargo jerárquico - empleados administrativos, capataces, supervisores, gerentes, directivos- era "diferente" por no estar afiliado al sindicato ni integrar las movilizaciones. Los operarios constituían el grupo más numeroso en la fábrica. Varios entrevistados hablarían de su actuación "en masa o en patota", haciendo hincapié en su poder corporal y no reflexivo. Ramiro y Sofía tenían al lado de su vivienda, ubicada sobre la avenida principal del barrio, un comedor y una pensión que trabajaron hasta comienzos de 1980. Desde allí recuerdan una toma de fábrica para ellos especialmente memorable:

Graciela (G): Y cuando eran las huelgas, ¿cómo eran? Ramiro (R): ¡ Uhhh! Eso sí que era fulero. ${ }^{14}$

Sofía (s): Era triste, ¿no? ¿En qué año fue que tenían puesto los tachos con las mechas?

R: Eso fue en el 70, pero anteriormente el sindicato hacía muchos paros. Y se llenaba de negrada todo esto acá. Tiraban bombas.

G: ¿Por acá también?

R: Sí. Iban y venían.

s: Sabés, las chicas de Renault que trabajaban, que venían de Alta Gracia en ómnibus, venía muy mucha gente, y venían los del sindicato con cadenas y ramas, y las hacían pegar la vuelta. "Vuelta, vuelta", como si

\footnotetext{
${ }^{14}$ Feo, desagradable.
} 
estuvieran arriando animales. Y una vez tomaron la fábrica. Pusieron la fábrica en marcha y hacían bulones. Y no dejaban entrar ni a la policía. Tomaron, pusieron tanques de 200 litros todos con nafta y ahí, mechas. ¿Sabés con qué hacían las gomeras? Sacaban los cueros de los Torinos nuevos, de los asientos y hacían las hondas y tiraban. Y rompían. Y decían que si llegaban a entrar... No llegaron a prender, porque si llegaban a prender eso, la cantidad de coches que volaban.

G: ¿Y eso cuándo habrá sido, en los sesenta, setenta?

R: En la época que empezaron los "montoneros". Vos sos muy jovencita, no te acordás (Ramiro, 75 años, comerciante jubilado; Sofía, 70 años, comerciante jubilada, julio de 2009).

La toma de fábrica aquí narrada por Ramiro y Sofía muestra un despliegue de fuerza corporal por parte de sindicalistas y obreros, que en su actuar masificado se transforman en "una negrada". Sin embargo, en la ocasión descrita se suma una violencia extra: los manifestantes agitan "cadenas y ramas", tratan a otras personas "como animales" 15 y son capaces de poner en peligro la planta. Ramiro sitúa el inicio de esta violencia en el momento de llegada de los "montoneros", para él responsables del cambio producido en el modo de actuar de los obreros. Esta cuestión también puede observarse en otros discursos. Según algunos vecinos, estas nuevas estrategias de protesta de los obreros se vinculan a la llegada a la fábrica de personas con cierta ideología de izquierda, llamadas "zurdos" o "montoneros". ${ }^{16}$ Manuel recuerda:

Manuel (м): Cuando Obregón Cano fue gobernador de Córdoba, la fábrica comenzó a cambiar ya totalmente. Porque dicen que, eso ya me lo cuentan, yo no

\footnotetext{
${ }^{15}$ Burgat (1996) indica que por el mecanismo de animalización las personas son destituidas de derechos y se les niega el reconocimiento a ser tratadas como un fin y no como un simple medio.

16 "Montoneros" inicia sus acciones en 1970, y en 1974, luego de un proceso de unificación, se articula con las Fuerzas Armadas Revolucionarias (FAR), con las Fuerzas Armadas Peronistas (FAP) y con "descamisados", adoptando el nombre de "montoneros".
}

estaba en transporte, dicen que los "montoneros" consiguieron que les dieran trabajo acá. Pero vos por ejemplo, sos obrero de fábrica, entraba uno y te decían: “¿Cuántos bulones hacés vos??" “50”. “A partir de hoy vas a hacer 10 ".

Graciela (G): ¿Quién lo hacía a eso?

M: Los que entraban, como quien dice "montoneros". Les exigían como quien dice que la producción la llevaran a cero.

G: ¿Pero tomaban a gente que era "montonera" en la fábrica?

M: Y sí, porque te exigían. Porque un poco te exigían que te dieran trabajo. Por eso entraban, en fin. Y se plegaron los estudiantes, de toda gente, en contra de Perón. Si cuando triunfó la Revolución del 55, estuve yo en el centro. Por ejemplo agarraban un animal, una cabra, un chivato, le cortaban la cabeza, vos sabés que chorrea sangre, lo ponían arriba del techo, del capo en el auto, y con ésos salían a hacer manifestaciones en el centro.

G: ¿Y qué quería decir eso?

M: Como si hubieran degollado al gobierno... Una cosa así sería porque sentido no tenía. Fue terrible, terrible eso (Manuel, 80 años, gastronómico jubilado, julio de 2009).

Manuel indica que la llegada de "montoneros" profundizó los inconvenientes en la fábrica y contribuyó a bajar su producción, principalmente durante la época del gobernador Obregón Cano - en otra charla hablaría de la "época de Cámpora"-.${ }^{17} \mathrm{El}$ trabajo a reglamento, como vimos, constituyó una de las estrategias de la conducción clasista del sindicato a inicios de la década de 1970 y, como refiere Manuel, también fue practicada por los "montoneros". De este modo, la introducción de tendencias de izquierda a la fábrica marca una transformación en la dinámica del trabajo. El recuerdo de Manuel se encuentra atravesado por su experiencia como peronista, ya que junto a su afirmación de que los "montoneros" y los estudiantes se plegaron "en

\footnotetext{
${ }^{17}$ Gobernador de Córdoba -1973-1974- por el partido peronista. Su gobierno, de tendencia de izquierda, fue derribado el 27 de febrero de 1974 por el jefe policial Antonio Domingo Navarro, con el apoyo de autoridades nacionales.
} 
contra de Perón" durante su tercer gobierno, describe el derrocamiento del peronismo ocurrido en 1955. Para Manuel, la oposición que derrocó al gobierno de Perón y las luchas políticas desarrolladas durante su tercera presidencia se mezclan a partir de 1973. Sus memorias superponen esos acontecimientos y se despegan de un tiempo histórico o cronológico. Muchas de las charlas con Manuel y su esposa Violeta se remitieron a la época del gobierno peronista entre 1946 y 1955 . Desde el momento en que les pregunté si eran peronistas al ver una foto de Eva Perón en el vidrio de la mesa del comedor, éste sería un tema recurrente que recordarían con entusiasmo en nuestras charlas. En varias oportunidades me recomendaron el libro La razón de mi vida de Eva Perón y un día Manuel me mostró un cartel en el que aparecía un Perón joven montado en un caballo. Sus recuerdos se centraban casi siempre en los dos primeros gobiernos de Perón -1946-1952 y 1952-1955-, época que coincide con la instalación de IKA en Córdoba. Así, Manuel y Violeta me mostrarían que los tiempos de las memorias son diferentes a los tiempos cronológicos, y que hay maneras de ordenar, reunir, significar el tiempo según cuáles sean las experiencias y marcos de significado. Acontecimientos que desde una perspectiva histórica se encontraban separados, desde las experiencias personales estaban amalgamados y tenían sentidos similares. Al preguntarle a Manuel sobre el "cordobazo", comentó:

Manuel (м): El asunto del "cordobazo", en aquel tiempo estaban Agustín Tosco, Atilio López, Salamanca... ¿Quién era el otro? Eran cinco o seis los que manejaban los gremios, como quien dice, más grandes de Córdoba. Y ésos fueron los que se plegaron e hicieron el "cordobazo", junto con algún estudiante de la Universidad.

Graciela (G): ¿Eran como gremialistas?

м: Eran gremialistas, eran las cabezas de los gremios, secretarios de los gremios. Y estas personas es como que han sido peronistas, no sabés si de extrema derecha, o de extrema izquierda al final. Fueron el extremo en contra del gobierno. Porque el segundo gobierno de Perón no fue como el primero. Su primer gobierno hizo un cambio en la República Argentina. Su segundo gobierno fue como si hubiera sido copado... no copado, pero le hacían la contra al gobierno los grandes capitales. Porque gobernaba para la clase media para abajo. Y acá están acostumbrados a gobernar para la clase media para arriba. Por eso fue el "cordobazo" (Manuel, julio de 2009).

En esta explicación aparecen unidos diferentes actores y acontecimientos. Si bien al momento del "cordobazo" René Salamanca no tenía aún una participación sindical relevante, Manuel lo ubica al lado de Agustín Tosco y Atilio López, dirigentes de Luz y Fuerza y de la Unión Tranviarios Automotor (UTA), respectivamente. Manuel enlaza luego el "cordobazo" con las luchas políticas de comienzos de 1970 y con el peronismo. Alude a tendencias políticas opuestas al gobierno de Perón y detalla que su "segundo" gobierno - 1973-1974 - no había sido igual al "primero" - 1946-1952 y 1952-1955-, que había representado "un cambio". Es decir, borra las fronteras entre el "cordobazo" y el último gobierno peronista y los vincula a partir de los conflictos que los atraviesan.

\section{GENTE DEL BARRIO Y DE OTROS LADOS}

El recuerdo de que las manifestaciones "más bravas" las generaron personas venidas "de afuera" presentaba un problema: que algunos vecinos habían formado parte de ellas. En varias entrevistas apareció sutilmente el hecho de que en el barrio residieron personas que eran delegados de la fábrica. No obstante, al consultar dónde podía encontrarlos para conversar, los vecinos me respondían que "se habían ido" y que "no quedaba ninguno". Según Sofía y Ramiro, si bien en el barrio habían vivido sindicalistas, éstos estaban "sobre todo en la Segunda Sección”. Sofía añadió que en la Primera Sección "había uno", pero que "estaba loco" y se había ido del barrio. De manera que aquellos vecinos 


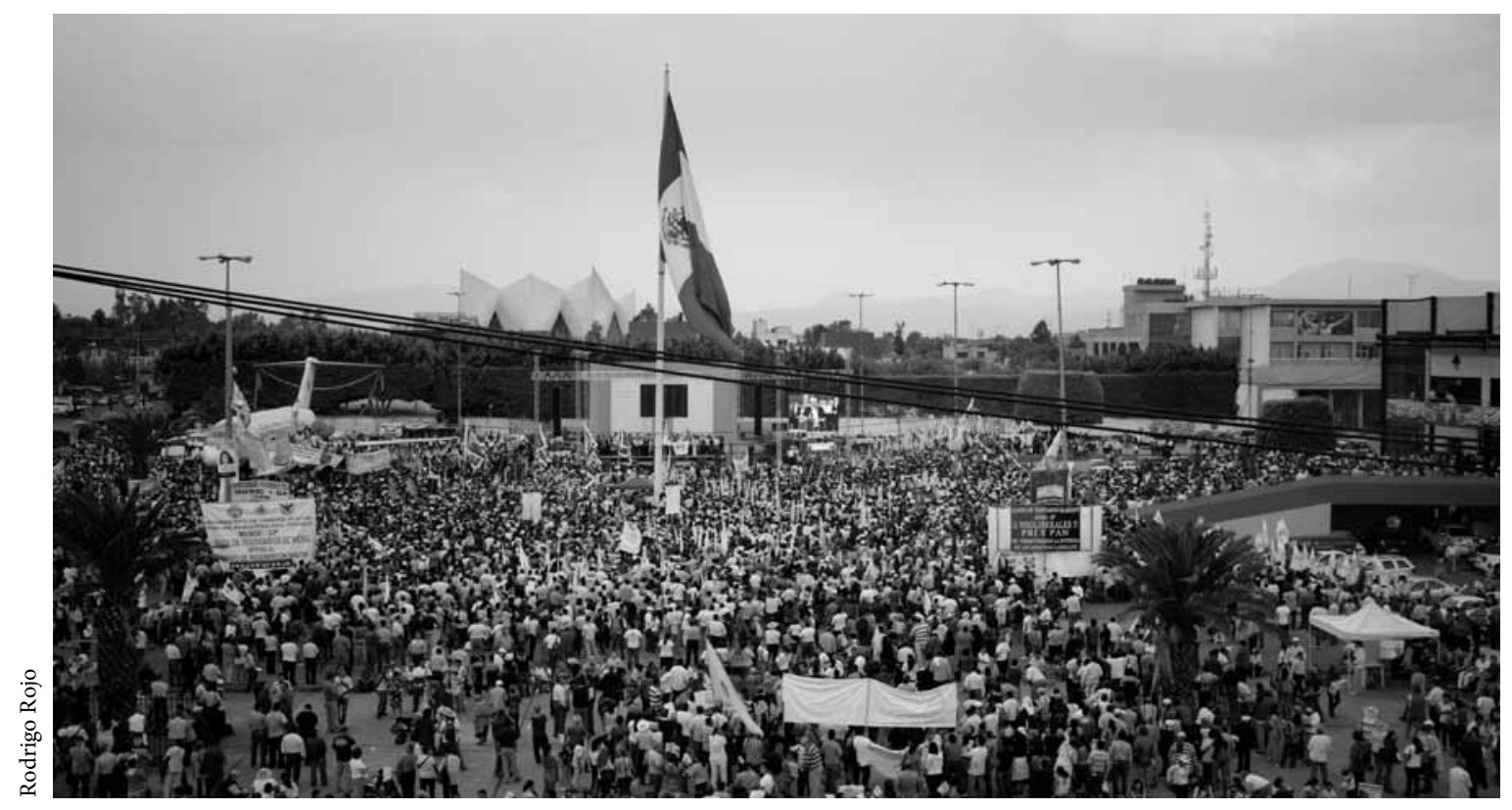

Mitin del candidato presidencial Andrés Manuel López Obrador en la explanada de la delegación Venustiano Carranza de la ciudad de México 17 de abril de 2012.

que fueron sindicalistas se encontraban en otras secciones y si estaban cerca se los desacreditaba llamándolos "locos".

Durante las entrevistas a vecinos extrabajadores de la fábrica ninguno mencionó haber tenido un papel activo en una protesta. En sus relatos, las tomas de fábrica parecen ser hechos protagonizados por otros, hechos que no presenciaron personalmente porque se habían ido del lugar antes de la instalación de la planta o en los que habían tenido un rol pasivo. Una de las pocas referencias a una toma de fábrica cercana fue la relatada por Pascual (76 años, supervisor de IKA y Renault jubilado), quien comenzó a trabajar en la empresa en 1959 y vive en Santa Isabel desde inicios de 1960. Una tarde, mientras me encontraba en la biblioteca del barrio, Pascual llegó y comenzamos a conversar. Me contó que presenció "una toma de fábrica brava" en la que gente del sindicato había encerrado a los directivos, mientras amenazaban con hacer explotar unos tambores de thinner si el ejército entraba a reprimir. Parecía ser la misma huelga de 1970 comentada por Ramiro y
Sofía. Pascual recordó que habían llegado tanques del ejército a la avenida que llevaba a la fábrica y que los soldados aguardaban la orden de entrar. Él formaba parte del grupo de trabajadores católicos que había buscado "apaciguar la cosas". Entonces uno de ellos salió por los alambrados del fondo y corrió hasta el arzobispado a buscar ayuda. Este compañero le pidió al arzobispo que interviniera "para evitar una masacre" y gracias a eso la toma de fábrica "había terminado bien". En su narración, Pascual marca una diferencia entre un grupo de empleados que se conocía previamente y quería evitar males mayores y aquellos que con sus métodos nuevos y violentos traían a todos el riesgo. Desde su punto de vista el actuar de estos últimos generaría la posibilidad de ser reprimidos por las fuerzas militares. Pascual no cuestiona la presencia de tanques del ejército en las calles ni la amenaza de represión. Resulta interesante advertir que en varias charlas los que aparecen como responsables de la represión no son los militares, sino los sindicalistas que elegían métodos riesgosos y actuaban más allá de los límites permitidos. 
En suma, en los relatos analizados los vecinos revelan diversas maneras de distinguirse y tomar distancia de una forma de protesta que se tornaba perniciosa para el trabajo fabril e imprudente para el barrio. En las memorias de estos antiguos vecinos, los operarios movilizados se convierten en "patoteros" que actúan en masa y sin reflexionar, y los "montoneros" o "zurdos" son caracterizados por su conducta prepotente y de descuido hacia el trabajo. Dichas descripciones permiten entrever la creencia de que quienes producían líos y hacían más violentas las protestas eran los "nuevos operarios", llegados hacia fines de la década de 1960 y comienzos de la de 1970 con ideas políticas de izquierda. Personas "de afuera" que desconocían las normas comunes y el modo de trabajar de quienes se encontraban en la fábrica y en el barrio desde el inicio. El clásico análisis de Elias y Scotson (2000) en Winston Parva resulta iluminador acerca de la manera en que los vecinos de Santa Isabel construyen memorias sobre esa "llegada". Para dichos autores, las "viejas fami-

lias" de la comunidad se diferenciaban de las "recién llegadas" por ciertas características de comportamiento distintivas y la unión de sensibilidades. Ser miembro de las "viejas familias" implicaba ser conocido en su localidad y conocerse desde varias generaciones atrás, lo que llevaba a adoptar un código de conducta y un alto grado de autocontrol. Esta forma de relacionarse implicaba cualidades tan compatibles con la amistad como con la enemistad mutua, pero sea cual fuere el caso actuaban para excluir a los recién llegados. Elias y Scotson muestran así el modo en que un grupo de personas es capaz de monopolizar las oportunidades de poder y utilizarlas para marginar y estigmatizar a otro grupo semejante, así como la forma en que estas circunstancias son vivenciadas en sus autoimágenes colectivas.

Las familias que llegaron a Santa Isabel en los primeros tiempos del barrio y de la empresa identificaron en los conflictos sindicales de la década de 1970 encabezados por militantes de izquierda una amenaza para su estilo de trabajo y de vida. Esto produjo una variedad de modos de diferenciarse y estigmatizar a ese grupo, y de construir una imagen de sí mismos como defensores de la tranquilidad y del trabajo. Esta complementariedad entre el carisma de propio grupo - los vecinos y los trabajadores pioneros - y la deshonra del otro - los negros, los zurdos, los violentos - constituye el aspecto central de las memorias sobre los obreros de la fábrica en movilización. Sin embargo, las memorias nunca son homogéneas, sino que presentan puntos de vista diversos y ambigüedades. Un relato diferente a los vistos hasta aquí es el de Ernesto, vecino hoy jubilado y exempleado administrativo de la Universidad. Ernesto me contó que llegó casi por casualidad al barrio, cuando un amigo lo invitó a recorrer la zona en moto porque había escuchado que allí se ofertaban lotes. El terreno era barato y se podía pagar en cuotas, así que Ernesto lo compró y comenzó a construir su casa "de a poco" y "con mucho esfuerzo". En 1969 se mudó a Santa Isabel con su esposa y su primer hijo, y durante ese año experimentó una aproximación a la política distinta a la que estaba acostumbrado: frente a la fábrica había un bar llamado "El Cimarrón", donde se reunían sindicalistas y delegados de esa época:

Graciela (G): ¿Usted vivía acá?

Ernesto (E): Sí. Y para colmo yo era medio liero, me mezclaba. Iba a reuniones, era de la Universidad. Yo me metía en unas reuniones que hacían al frente de la fábrica donde había un restaurant, un bar que se llamaba "Cimarrón", y ahí se hacían unas reuniones donde había pesos pesados del smata. Tosco, Salamanca, te estoy hablando del tiempo de Elpidio Torres.

G: ¿Usted los vio ahí?

E: Estaban ahí. Yo me metía ahí. Y algunos preguntaban... Pero me conocía la gente de acá: “No, no. Es de acá - le decían-, es colaborador del centro vecinal y del barrio". Así es que mi familia... Bueno, no es que era de ultraizquierda. No tengo miedo que me cataloguen, tengo un concepto cristiano alto. Posiblemente mi actividad en la Universidad más todo esto que hacía me afectó (Ernesto, 74 años, empleado público jubilado, noviembre de 2008). 
Ernesto construye su relato como alguien interesado en política, perteneciente a la Universidad y delegado, que admiraba también a los dirigentes sindicalistas de ese momento. No obstante, al mismo tiempo se adscribió como alguien que no era "de ultraizquierda" y tenía "un concepto cristiano alto". Si bien en la actualidad "El Cimarrón" es sólo una construcción abandonada ${ }^{18}$ que poco recuerda la época en la que pasaban por allí cientos de obreros o en donde se organizaban reuniones políticas, constituye para Ernesto un lugar de memoria que remite a una época en que la politización llega al barrio y tiene al "cordobazo" como centro:

Ernesto (E): Para qué decir el 29 de mayo [día del "cordobazo"], todos a pie.

Graciela (G): ¿Y estaba aquí?

E: Estaba aquí, pero yo estaba en el trabajo... y yo pertenecía al cuerpo de delegados de mi dependencia de la facultad.

G: ¿Sabía que iba a pasar eso?

E: Y como venía la situación del país, uno ya lo percataba. Pero lo grande, [lo que] sorprendió fue la magnitud de la toma de la fábrica. Los rehenes. Yo tenía gente conocida, acá del barrio que estaban ahí encerrados y había que llevarles la comida.

G: ¿Pero ese 29 hubo una salida? ¿La toma de fábrica cuándo fue?

E: Fue antes del 29. El 29 es allí cuando disponen, en tiempo cuando se pone más bravo Onganía, entonces acá deciden entre Tosco, Elpidio Torres, Atilio López. [...] Yo sabía que se estaba gestando algo, pero no me daba cuenta de la magnitud. Tuvo que ser así. Después analizándolo bien, tenía que ser así. Estábamos sojuzgados. Yo tenía una pequeña bibliotequita con unos libros y tenía que estar cavando un pozo para enterrarlo porque todos tenían miedo... Una época bravísima (Ernesto, noviembre de 2008).

De acuerdo con Ernesto, la movilización del "cordobazo" era de esperarse dadas las medidas restrictivas

\footnotetext{
${ }^{18}$ Luego de pasar por distintos dueños, cerró en 2001 debido a la crisis económica que afectó a la fábrica y al barrio, como me relató el último concesionario que tuvo el local.
}

implementadas por el gobierno de Onganía en la Universidad, la política, la cultura y la economía. Para Ernesto, la toma de fábrica "antes del 29" fue particularmente importante por "su magnitud" y porque allí había "gente conocida", lo que expresa cercanía y solidaridad con los manifestantes. Ernesto acota que había sido afectado por su actividad en la Universidad, una institución según él comprometida social y políticamente con la sociedad. De ahí que su relato muestre en primer lugar el rol de delegado universitario y luego el de vecino, construye una representación de la vida universitaria distintivamente política y cercana a la gente. Coloca en paralelo el lugar de los delegados universitarios y sindicales, en tanto que ambos comparten la lucha contra un gobierno autoritario que los somete. Esta construcción de cierta igualdad, debido a la necesidad de unirse ante un poder mayor, impide a Ernesto estigmatizar las protestas sindicales. Como puntualiza Elias: "un grupo puede estigmatizar a otro sólo mientras esté bien establecido en posiciones de poder de las cuales el grupo estigmatizado se encuentra excluido" (Elias, 1998: 89). Se observa entonces que el análisis de las memorias sobre el trabajo y la movilización en este barrio implica necesariamente desentrañar el lugar que ocupan los entrevistados, así como las relaciones que construyen entre los grupos que se encuentran y que llegan al barrio, a veces de conflicto y a veces de convivencia.

\section{PALABRAS FINALES: MEMORIAS Y MOVIMIENTOS}

En opinión de Vera da Silva Telles (2006: 176), las circunstancias actuales del mercado de trabajo no representan para los jóvenes una degradación de las condiciones, mejores o más promisorias, de otros tiempos. Ellos entraron en un mundo ya cambiado, en que el trabajo precario y el desempleo componen un estado de cosas con el cual tienen que lidiar, y estructuran una experiencia en todo diferente de la generación anterior. Al marcar una diferencia con 


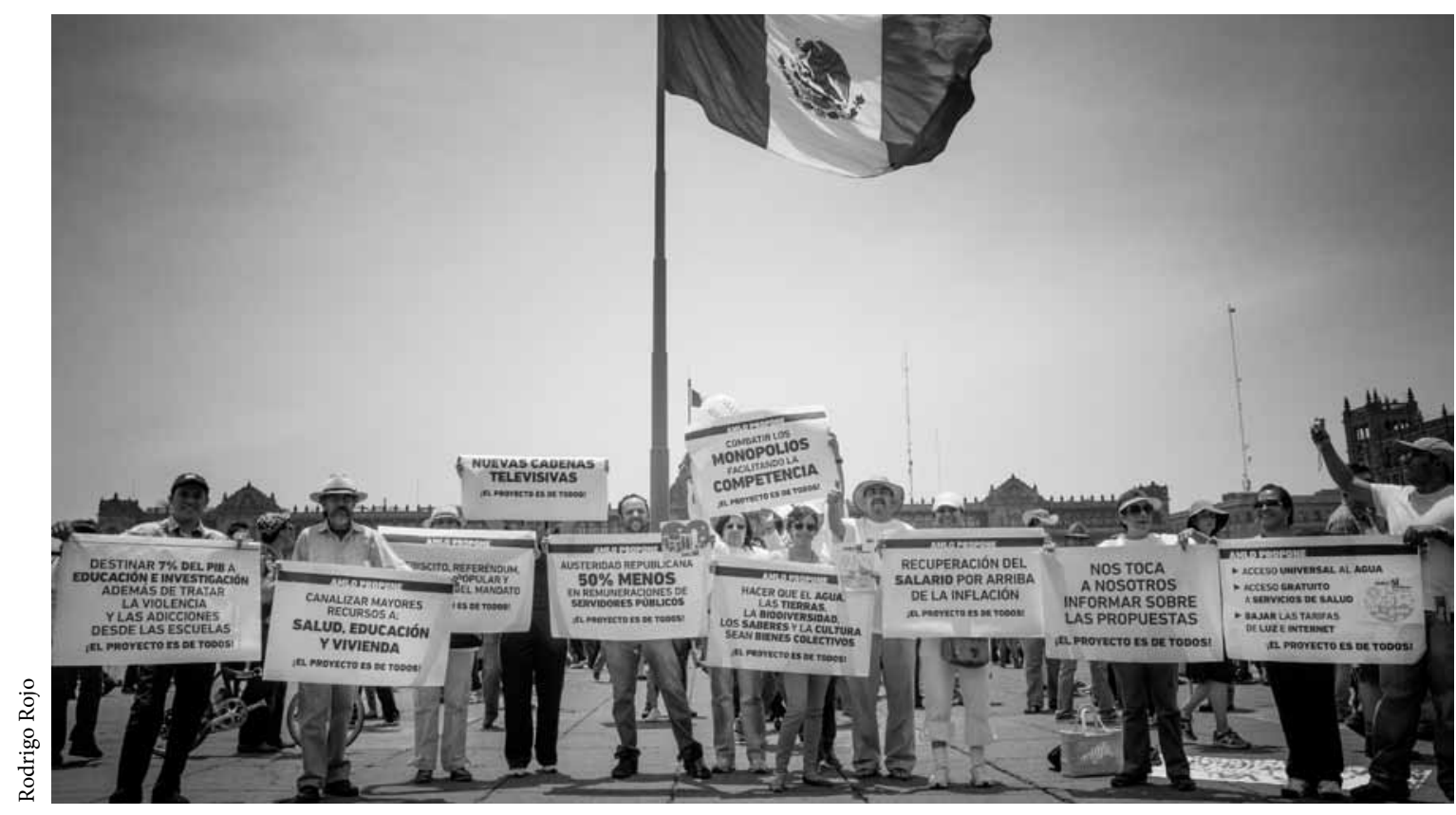

¡Nos toca a nosotros informar sobre las propuestas!, Centro Histórico de la ciudad de México, 20 de mayo de 2012.

esta cuestión, los entrevistados que compartieron conmigo sus recuerdos en el barrio Santa Isabel habían tenido en el pasado otras experiencias laborables y rememoraban un tipo de trabajo industrial y un estilo de vida distinguido que "se había perdido". Como vimos, el encuentro del barrio con la fábrica se producía principalmente en las calles por las que transitaban cotidianamente caravanas de trabajadores y movilizaciones sindicales periódicas. Si bien estas formas colectivas de transitar ocurrían en lugares similares - las calles - y con gran parte de los mismos participantes, los vecinos acentuaban sus diferencias y contrastes.

Los relatos sobre las caravanas de trabajadores que en cada salida de la fábrica se transformaban en un esperado y admirado desfile fueron recurrentes. Estas caravanas eran rememoradas con un tono festivo y sin presentar conflictos, como ocasiones que suponían un espectáculo "digno de ver". Algo diferente ocurrió en relación con los recuerdos sobre las movilizaciones sindicales, que aparecieron en los relatos con un carácter conflictivo y distante principalmente: los obreros salían en masa, utilizaban la violencia de manera explícita y traían riesgo al barrio. Los vecinos entrevistados sugirieron que a partir de la década de 1970 llegaron a la fábrica "nuevos" trabajadores con ideas políticas de izquierda - "eran zurdos"-, llevando en sus cuerpos un color particular - "eran negros" - y abandonando su lugar distinguido para actuar "en masa". La perspectiva de Elias y Scotson (2000) nos acompaña a observar el modo en que aquellas personas llegadas primero al barrio y que se conocían entre sí pudieron construir una posición de poder desde la cual marginar a los individuos y grupos llegados posteriormente. Para los entrevistados el "mejor" momento de relación entre la fábrica y el barrio se aparta de los conflictos sindicales y excluye a los dirigentes y operarios de izquierda. En contraposición al lugar prestigioso dado a los empleados de Kaiser en la década de 1960, los trabajadores que arribaron en la década siguiente presentan en las memorias modos de actuar que afectan la reputación del barrio. Si bien buena parte de los trabajos 
académicos escritos sobre este periodo se aproximan a las movilizaciones obreras en términos políticos y como expresiones de rebeldía hacia los poderes centrales en Buenos Aires, se torna necesario indagar los sentidos sociales y de construcción de prestigio que atraviesan estas memorias locales. Examinar este aspecto podría ayudarnos a comprender la vinculación entre los cambios en la empresa, el contexto de violencia política en los años setenta y las sensibilidades implicadas en lo que los vecinos consideran el inicio de cambios en su estilo y nivel de vida.

Eventos amplios y experiencias privadas se cruzan y permiten percibir miedos, rechazos, orgullo y afecto expresados en los cuerpos de los entrevistados, en los tonos de sus relatos, en los recuerdos que eligen mostrar u ocultar. La mayoría de las personas entrevistadas buscaron ubicarse lejos de la "masa obrera" y cercanas a una vida de "trabajadores y gente tranquila". No obstante, aparecieron también recuerdos ambiguos y zonas grises que mostraban en un mismo relato la admiración y adhesión hacia el modo de hacer política de Salamanca, el rechazo a cualquier identificación con lo "zurdo" y la permanencia del sentimiento peronista. Las memorias registradas nos ayudan a complejizar la mirada con la que suele estudiarse el movimiento obrero y nos acercan a planos no explorados de sensibilidades que se hacen presentes a partir de la evocación. Como se señaló, las memorias que construimos no suponen sólo representaciones, sino también formas de sentir, fuerzas que nos afectan y por medio de las cuales afectamos (Gondar y Dodebei, 2005), son dinámicas, se transforman y toman distintas tonalidades. Esto implica no pretender encontrar sus formas definitivas, sino dejarnos llevar para seguir y sentir su movimiento.

\section{BIBLIOGRAFÍA}

Beaud, Stephane y Michel Pialoux, 2006, "Rebeliões urbanas e desestruturação das classes populares (França, 2005)", en Tempo Social. Revista de Sociologia da USP, vol. 18 , núm. 1 .
Brennan, James, 1996, El Cordobazo. Las guerras obreras en Córdoba 1955-1976, Editorial Sudamericana, Buenos Aires. — y Mónica Gordillo, 2008, Córdoba rebelde. El cordobazo, el clasismo y la movilización social, Editorial de la Campana, La Plata.

Burgat, Florence, 1996, "La logique de la légitimation de la violence: animalité vs. humanité", en Françoise Héritier (comp.), Séminaire: De la Violence, Éditions Odile Jacob, París.

Comisión y Archivo Provincial de la Memoria, 2009, Topografía de la rebeldía, Comisión y Archivo Provincial de la Memoria, Argentina.

Da Silva Telles, Vera, 2006, "Mutações do trabalho e experiência urbana”, en Tempo Social. Revista de Sociologia da USP, vol. 18, núm. 1.

Elias, Norbert, 1998, "Ensayo teórico sobre la relación entre establecidos y marginados”, en Norbert Elias, $\mathrm{La} \mathrm{ci}$ vilización de los padres y otros ensayos, Norma, Santa Fe de Bogotá.

- y John Scotson, 2000, Os Estabelecidos e os Outsiders, Jorge Zahar Editor, Río de Janeiro.

Gondar, Jô y Vera Dodebei (orgs.), 2005, O que é memória social?, Contra Capa, Río de Janeiro.

Gordillo, Mónica, 1999, Córdoba en los sesenta. La experiencia del sindicalismo combativo, Universidad Nacional de Córdoba, Córdoba.

Halbwachs, Maurice, 2004, La memoria colectiva, Prensas

Jelin, Elizabeth, 2002, Los trabajos de la memoria, Siglo XXI, Madrid, Buenos Aires.

Malecki, Sebastián, 2010, "Intelectuales y obreros en la Córdoba de los 60-70. Una aproximación a las experiencias de Pasado y Presente y Sitrac-Sitram”, en Héctor Schmuckler, Sebastián Malecki y Mónica Gordillo (eds.), El obrerismo de "Pasado y Presente". Documento para un dossier (no publicado) sobre Sitrac-Sitram, Ediciones Al Margen, La Plata.

Neiburg, Federico, 1988, Fábrica y villa obrera: historia social y antropología de los obreros del cemento, Centro Editor de América Latina, Buenos Aires.

Ratier, Hugo, 1972, Cabecita negra, Centro Editor de América Latina (Colección La Historia Popular), Buenos Aires.

Rocca, Cristina, 2005, Las bienales de Córdoba en los sesenta: arte, modernización y guerra fría, Editorial Facultad de Filosofía y Humanidades, Universidad Nacional de Córdoba, Córdoba.

Tedesco, Graciela, 2010, “Aquí es toda gente trabajadora...' Experiencias cotidianas y memorias sobre el pasado reciente en un barrio de la ciudad de Córdoba", tesis de doctorado en ciencias sociales, Instituto de Desarrollo Económico y Social, Universidad Nacional de General Sarmiento, Argentina. 